Jpn. J. Med. Sci. Biol., 48, 49 - 59, 1995.

\title{
DEVELOPMENT AND USEFULNESS OF THE GELATIN-PARTICLE- AGGLUTINATION TEST FOR TITRATION OF ANTIBODIES AGAINST DIPHTHERIA, PERTUSSIS AND TETANUS TOXINS
}

\author{
Kikuko MIYAMURA, Seiji SADAHIRO1, Toshifumi KONDA1, \\ Motohide TAKAHASHI1, Ryuichi FUJINO2, Yuko NISHIMURA2, \\ Hideo MIYAKOSHI2, Kiyoshi HORIUCHI3, Youichi FURUYA4, \\ Tsutomu KUBOTA4, Haruo WATANABE5, Sakae INOUYE \\ and Shudo YAMAZAKI6
}

Department of Epidemiology, 5Department of Bacteriology, 6Director-General, National Institute of Health, 1-23-1 Toyama, Shinjuku-ku, Tokyo 162, 1 Department of Bacterial and Blood Products, National Institute of Health, 4-7-1 Gakuen, Musashimurayama-shi, Tokyo 208, 2Diagnostic Research Laboratories, Fujirebio Inc., 51 Komiya-cho, Hachioji-shi, Tokyo 192, 3Chiba Serum Institute, 2-6-1 Konodai, Ichikawa-shi, Chiba 272 and 4Shizuoka Prefectural Institute of Public Health and Environmental Science, 4-27-2 Kitaando, Shizuoka 420

(Received November 1, 1994. Accepted December 6, 1994)

SUMMARY: The gelatin-particle-agglutination (PA) test for titrating antibodies against diphtheria, pertussis and tetanus toxins was developed and used for assaying 65 sera from healthy children to assess the antitoxin acquisition in relation to the administration of adsorbed diphtheria-purified pertussis-

宮村紀久子·井上 栄 (国立予防衛生研究所感染症疫学部)

山崎修道(国立予防衛生研究所)

貞弘省二·近田俊文·高橋元秀 (国立予防衛生研究所細菌·血液製剂部 武蔵村山市学園 4-7-1)

藤野隆一·西村優子.宮腰秀夫 (富士レビオ(株)検查薬研究所 八王子市小宮町51)

堀内 清(千葉県血清研究所 市川市国府台2-6-1)

古屋洋一·窪田 勉 (静岡県衛生環境センター 静岡市北安東27-2)

渡邊治雄 (国立予防衛生研究所細菌部) 
tetanus (DPT) combined vaccine. The antitoxin titers obtained by the PA test and the conventional methods were correlated well; the correlation coefficient of the diphtheria antitoxin titers between the PA test and the cell culture method was 0.908 , that of the tetanus antitoxin titers between the PA test and the passive hemagglutination test 0.968 , and that of anti-pertussis toxin titers between the PA test and polystyrene-ball ELISA 0.885 . The PA test was shown to be useful in both developed and developing countries, since it is simple to perform, sensitive and specific, and the three antitoxins can be titrated by the same procedure.

\section{INTRODUCTION}

For implementation of vaccination against diphtheria, pertussis and tetanus, seroepidemiological survey is the most reliable method to assess the prevalence of the diseases and the effects of vaccination and to find the individuals who should be vaccinated. The serological tests, however, are often hampered because of the requirement for expensive equipment or for complicated procedures which often need the training of workers. Moreover, a distinct assay method should be used for each disease. Since trivalent diphtheria-pertussistetanus (DPT) vaccine was being used worldwide, it will be practically of great benefit, if these three antibodies can be assayed by the same procedure.

In this report, we describe development of the gelatin-particle-agglutination (PA) test for determination of the three antibodies. The gelatin particles used as a carrier of the antigens were the same as those used for HTLV-1 and HIV antibody assay $(1,2)$. The test has routinely been applied for screening at blood banks and other institutions. The test is simple and rapid to perform and does not require any expensive equipment.

We applied the test we developed to the surveillance of Japanese healthy children for the antibodies, and the antibody titers against the three antigens were compared in relation to the vaccination history. The test proved to be not only simple to perform but also sensitive and specific. Therefore, it is suitable to perform in developing countries, where WHO has reinforced the Expanded Program of Immunization (EPI). 


\section{MATERIALS AND METHODS}

Preparation of PA reagents: The gelatin particles used were artificial spherical ones made of gelatin and gum arabic (3). The gelatin particles were activated with $2.5 \mu \mathrm{g}$ of tannic acid/ml for $10 \mathrm{~min}$ at $37 \mathrm{C}$, washed, mixed with an equal volume of each antigen, and incubated for $60 \mathrm{~min}$ at $37 \mathrm{C}$. The particle suspensions were then lyophilized and stored at $4 \mathrm{C}$ until used.

Antigens used for coating gelatin particles: Tetanus and diphtheria toxoids purified for vaccine production were used. The original tetanus toxin contained $0.594 \mathrm{mg}$ protein $/ \mathrm{ml}$ and $250 \mathrm{Lf} / \mathrm{ml}$, and diphtheria toxin $2.438 \mathrm{mg}$ protein $/ \mathrm{ml}$ and $1,100 \mathrm{Lf} / \mathrm{ml}$. Pertussis toxin (PT), a preparation for acellular pertussis vaccine, was purified from a culture of Tohama strain by salting out with ammonium sulfate, zonal centrifugation, and collecting separately from the filamentous hemagglutinin (FHA) (4). It contained $1.05 \mathrm{mg}$ protein/ml and 58,000 ELISA units/ml.

Reference antibodies: Reference materials (lyophilized) used were the national standard tetanus antitoxin (immune horse serum) lot 3 , with a titer of 50 international unit (IU)/ampoule, the national standard diphtheria antitoxin (immune horse serum) lot 9, 1,060 IU/ampoule, and anti-PT-anti-FHA human immunoglobulin lot JNIH-10, containing 250 anti-PT ELISA unit (EU)/ampoule, and 400 anti-FHA EU/ampoule. Before use, each was dissolved in saline and it was diluted to a desired concentration.

Sample sera: The samples were 65 sera collected from healthy children in Shizuoka Prefecture in 1990 for the purpose of pertussis seroepidemiology under the project of the National Epidemiological Surveillance of Vaccine Preventable Diseases $(5,6)$. The donor's ages and vaccination histories are shown in Table II.

$P A$ test for antibody titration: The procedures were the same as described for the HTLV-I antibody assay (1). Twofold serial dilutions $(25 \mu \mathrm{l})$ of a sample serum were made on a U-bottomed 96 -well microplate and each dilution was mixed with an equal volume of a sensitized particle suspension. The mixtures were allowed to stand for $2 \mathrm{hr}$ at room temperature and read for agglutination with the naked eye. To the first well of the serum dilutions, added were nonsensitized gelatin particles instead of sensitized ones to serve as a control for nonspecific reaction. The highest dilution showing positive agglutination was determined and the PA titer was expressed as twice the highest net serum dilution factor.

Passive hemagglutination (PHA) test for tetanus antitoxin (7): A 2.5\% (V/V) suspension of tanned, formalinized sheep red blood cells (FSRC) was sensitized with an equal volume of purified tetanus toxoid $(15 \mathrm{Lf} / \mathrm{ml})$ for $30 \mathrm{~min}$ at $37 \mathrm{C}$, followed by washing and resuspending in $2.5 \%(\mathrm{~V} / \mathrm{V})$ in saline. Serum samples were each diluted 1:5 with saline, inactivated for $30 \mathrm{~min}$ at $56 \mathrm{C}$, and absorbed with $0.05 \mathrm{ml}$ of $20 \%$ (V/V) unsensitized FSRC per $\mathrm{ml}$ of a serum dilution for 60 
min at $37 \mathrm{C}$, and centrifuged. The supernatant served for assay. Three lines of $25 \%$ increasing serial dilutions of each serum sample were made on a microplate and the average value was taken as HAU.

Cell culture method (CCM) for diphtheria antitoxin: The micro-cell-culturecolor-change method with VERO cells (8) was used.

PS-ball ELISA for anti-pertussis toxin: A commercially available ELISA Kit for anti-pertussis toxin assay (Takeda Chemical Industries Ltd., Osaka) with antigen-coated polystyrene balls as the solid phase (the PS-ball ELISA method) $(5,9,10)$ was used according to the manufacturer's manual.

$D P T$ vaccine for immunization: An adsorbed diphtheria-purified pertussistetanus combined vaccine (4) commercially available was used.

\section{RESULTS}

\section{Preparation of PA Reagents}

The gelatin particles were sensitized by mixing with each antigen as described in Materials and Methods. The optimal conditions for $\mathrm{pH}$ of the buffer and antigen concentration for sensitization with each antigen were investigated with their reference antisera and three kinds of gelatin particles with different electrophoretic mobilities.

The conditions tested for tetanus and diphtheria toxoids were the $\mathrm{pH}$ range from 5.0 to 8.0 in $0.15 \mathrm{M}$ PBS and the antigen concentrations ranging from 5 to $300 \mu \mathrm{g} / \mathrm{ml}$. Those for pertussis toxin were the $\mathrm{pH}$ range of 6.0-8.5 and the antigen concentrations of $5-80 \mu \mathrm{g} / \mathrm{ml}$. The optimal conditions obtained preparing the PA reagents and the results of the PA test with the reference antiserum are shown in the upper part of Table I.

Based on the results, the sensitivity and the theoretical value were calculated: PA at 1:16 corresponded to $0.08 \mathrm{HAU}$ for tetanus antitoxin, $0.016 \mathrm{IU}$ for diphtheria antitoxin and 1.6 EU for anti-pertussis toxin.

\section{Antitoxin Titration of Sera from Healthy Children}

According to the results shown in Table I, the gelatin particles coated separately with each of the three antigens were prepared, with which the sera from healthy children were assayed (Table II). Comparisons of the results with those of the conventional assays are shown in Fig. 1. With all three antigens, high correlations were demonstrated: the correlation coefficients calculated 
Table I. Preparation of the PA reagents and the results of the PA test

\begin{tabular}{|c|c|c|c|}
\hline & Tetanus & Diphtheria & Pertussis \\
\hline $\begin{array}{l}\text { Optimal pH for } \\
\text { sensitization } \\
\text { Ant igen concentration }\end{array}$ & $\begin{array}{l}\mathrm{pH} 6.0 \\
150 \mu \mathrm{g} / \mathrm{m} 1\end{array}$ & $\begin{array}{l}\mathrm{pH} 6.0 \\
150 \mu \mathrm{g} / \mathrm{m} 1\end{array}$ & $\begin{array}{l}\text { pH } 8.0 \\
10 \mu g / m 1\end{array}$ \\
\hline $\begin{array}{l}\text { Reference antibody } \\
\text { Conventional method } \\
\text { PA titer } \\
\text { PA sensitivity } \\
\text { at PA } 1: 16\end{array}$ & $\begin{array}{l}10 \mathrm{HAU} / \mathrm{m} 1 \\
1: 2,048 \\
0.08 \mathrm{HAU} / \mathrm{m} 1\end{array}$ & $\begin{array}{l}1 \mathrm{IU} / \mathrm{m} 1 \\
1: 1,024 \\
0.016 \mathrm{IU} / \mathrm{m} 1\end{array}$ & $\begin{array}{l}25 \mathrm{EU} / \mathrm{m} 1 \\
1: 256 \\
1.6 \mathrm{EU} / \mathrm{m} 1\end{array}$ \\
\hline $\begin{array}{l}\text { PA sensitivity on human } \\
\text { sera tested in this } \\
\text { experiment } \\
\text { at PA } 1: 16\end{array}$ & $0.10 \mathrm{HAU} / \mathrm{m} 1$ & $0.042 \mathrm{IU} / \mathrm{m} 1$ & $1.2 \mathrm{EU} / \mathrm{m} 1$ \\
\hline
\end{tabular}

among those with positive results in at least either of the two methods were 0.968 between PHA and PA for tetanus antitoxin, 0.908 between CCM and PA for diphtheria antitoxin and 0.885 between EU and PA for anti-pertussis toxin.

From the data shown in Fig. 1, regression analyses were made and the sensitivities of the PA tests were calculated. The corresponding antibody titers obtained by the conventional assays at PA 1:16 were $0.10 \mathrm{HAU} / \mathrm{ml}$ for tetanus, $0.042 \mathrm{IU} / \mathrm{ml}$ for diphtheria and $1.2 \mathrm{EU} / \mathrm{ml}$ for pertussis.

Concerning the tetanus antitoxin assay, the sensitivity was nearly that expected from the data of the reference antitoxin as shown to the bottom of Table I; the PA titer at 1:16 corresponded to $0.10 \mathrm{HAU} / \mathrm{ml}$ as compared with 0.08 $\mathrm{HAU} / \mathrm{ml}$ in the reference antitoxin test. As shown in Fig. 1, when PA at 1:16 and higher was taken as tetanus antitoxin positive, 36 HAU-positive samples (over $0.02 \mathrm{HAU} / \mathrm{ml}$ ) were all positive, and when PA at 1:32 and higher was taken as positive, only one (No. 72, $0.119 \mathrm{HAU} / \mathrm{ml}$ ) was in the negative category.

Concerning the diphtheria antitoxin assay, the PA titer at 1:16 corresponded to $0.04 \mathrm{IU} / \mathrm{ml}$ of the CCM titer, 1/2.6 less sensitive than expected from the data of reference antitoxin shown in Table I. As a result, when PA 1:16 and higher were considered as positive, two of 11 sera possessing CCM titers of $0.02-0.08 \mathrm{IU} / \mathrm{ml}$ were in the negative category, and seven of these 11 sera became negative when PA 1:32 and higher were taken as positive. 

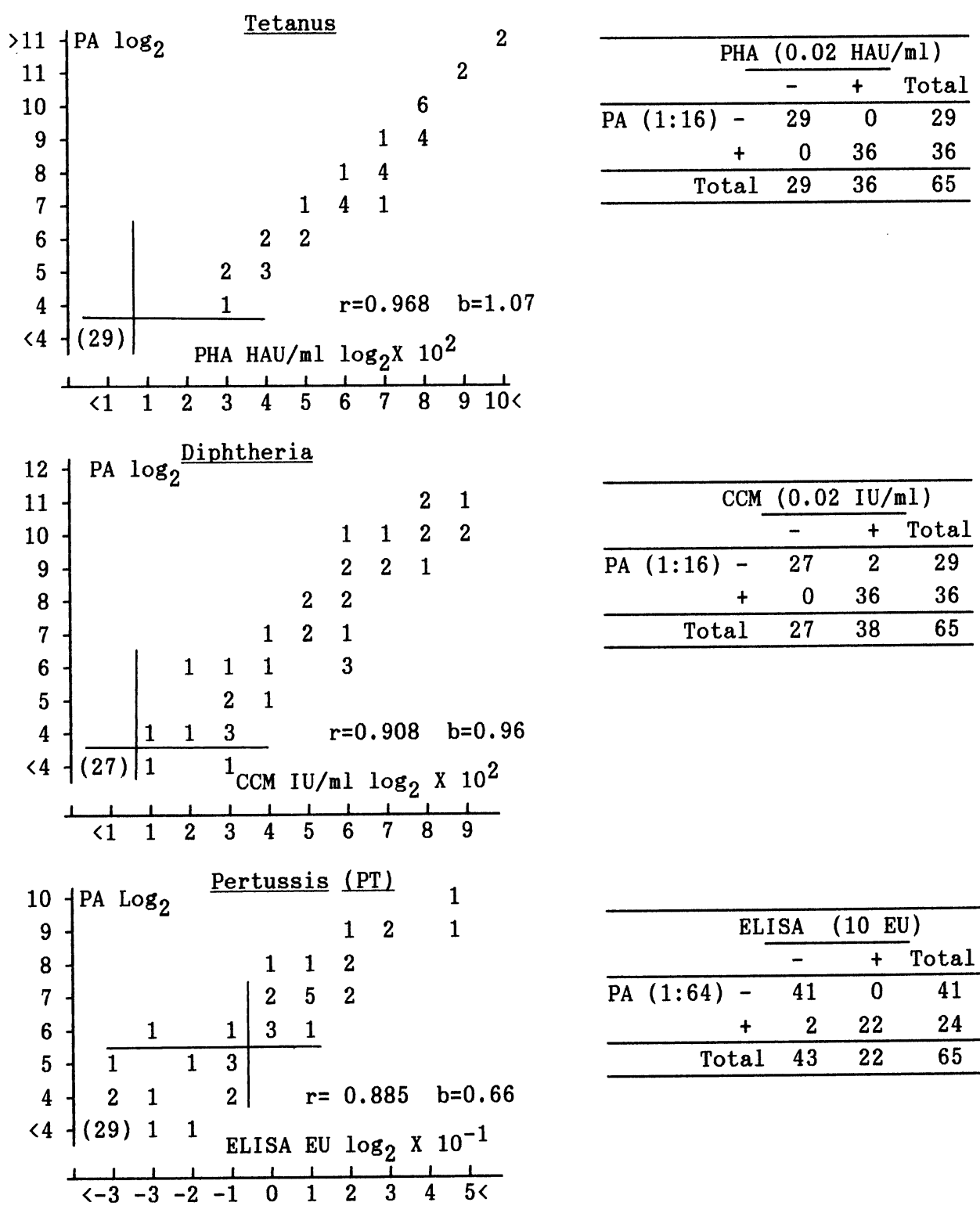

\begin{tabular}{|c|c|c|c|c|}
\hline & \multicolumn{2}{|c|}{ ELISA } & \multicolumn{2}{|c|}{$(10 \mathrm{EU})$} \\
\hline & & - & + & Total \\
\hline \multirow[t]{2}{*}{$\overline{\mathrm{PA}(1: 64)}$} & - & 41 & 0 & 41 \\
\hline & + & 2 & 22 & 24 \\
\hline & tal & 43 & 22 & 65 \\
\hline
\end{tabular}

Fig. 1. Correlation in antibody titers between PA and the conventional methods. Conventional methods for antibody titration were passive hemagglutination (PHA) for tetanus antitoxin, micro-cell-culturecolor-change method with VERO cells (CCM) for diphtheria antitoxin, and ELISA with antigen-coated polystyrene balls (PS-ball ELISA method) for anti-pertussis toxin. " $r$ " indicates correlation coefficient and " $\mathrm{b}$ " regression coefficient. 
To increase sensitivity, another lot of the PA reagent sensitized with the antigens at a higher concentration $(300 \mu \mathrm{g} / \mathrm{ml})$ was prepared. With this lot, five of the seven samples with low PA titers were assayed; four (No. 56, 57, 70 and 71) showed elevated titers by one dilution and another one (No.99) unchanged (see Table II). The difference between the hyperimmune reference antibody and individual human sera can be explained for by the difference in the avidity of the antibodies.

Concerning pertussis toxin antibody assay, the PA titers at 1:16 (corresponding to $1.2 \mathrm{EU} / \mathrm{ml}$ ) were close to the lowest detectable level of ELISA $(1.0 \mathrm{EU} / \mathrm{ml})(10)$, and all samples with $>10 \mathrm{EU} / \mathrm{ml}$, the level suggested as antipertussis toxin positive by others (11), showed the PA titers of $>1: 64$. When the samples lower than $10 \mathrm{EU} / \mathrm{ml}$ were considered, however, some inconsistency was noted between PA and ELISA.

Correlation of the Titers of the Three Antibodies with the Vaccination History

1) The tetanus antitoxin and vaccination history. All 35 children who had been vaccinated more than once showed the tetanus antitoxin in both PA and PHA. One (No. 71 in Table II) of 30 children who had not reportedly been vaccinated showed some tetanus antitoxin in both PA (1:32) and PHA $(0.19$ $\mathrm{HAU} / \mathrm{ml}$, data not shown). Since the case had also some diphtheria antitoxin of the minimum detectable titer, it is most likely that the case had received a vaccine at least once.

The results showed that detection of the antitoxin should indicate a history of tetanus vaccination including DPT vaccine, because the tetanus antibody can not be acquired naturally (12).

2) Relationship among the three antitoxins. Of the 65 children, from whom samples were obtained, most that had reportedly received DPT vaccination contained antibodies against diphtheria, pertussis and tetanus toxins. Of the 65 samples tested, five gave inconsistent results with the tetanus antitoxin; one (No. 15) in diphtheria and the other four in pertussis (No. 57 was excluded from the diphtheria antitoxin-negative category since it was positive by the improved reagent). No. 15 in Table II had antibody only to diphtheria on a minimal detectable level. The sample showed also a minimum titer by the conventional CCM test ( $0.02 \mathrm{IU} / \mathrm{ml}$, data not shown) and thus it might be a specific antibody to diphtheria or some related antigens.

The other three had both tetanus and diphtheria antitoxins but lacked detectable anti-pertussis toxin antibody (No. 57, 71, 72). Their negative results 
Table II. DPT vaccination history and antibody titers against diphtheria, pertussis and tetanus toxins determined by the PA test

\begin{tabular}{|c|c|c|c|c|c|c|c|c|}
\hline \multirow{2}{*}{$\begin{array}{c}\text { Code } \\
\text { No. }\end{array}$} & \multicolumn{4}{|c|}{ Vaccination history** } & \multirow[t]{2}{*}{ * Age } & \multicolumn{3}{|c|}{ PA titer } \\
\hline & $I-1$ & $\mathrm{I}-2$ & $I-3$ & II & & Tetanus & Diphtheria & Pertussis \\
\hline $\begin{array}{r}1 \\
2 \\
3 \\
4 \\
5 \\
6 \\
7 \\
8 \\
9 \\
10\end{array}$ & $\begin{array}{l}\bar{z} \\
\bar{z} \\
\bar{z} \\
\bar{z} \\
\bar{z} \\
\bar{z}\end{array}$ & $\begin{array}{l}\bar{z} \\
\bar{z} \\
\bar{z} \\
\bar{z} \\
\bar{z} \\
\bar{y}\end{array}$ & $\begin{array}{l}\bar{z} \\
\bar{z} \\
\bar{z} \\
z \\
\bar{z} \\
\bar{z}\end{array}$ & $\begin{array}{l}\bar{z} \\
\bar{z} \\
\bar{z} \\
\bar{z} \\
\bar{z} \\
\bar{y}\end{array}$ & $\begin{aligned} & 1 \\
& 1 \\
&< \\
& 1 \\
& 1 \\
& 1 \\
& 1 \\
& 1 \\
& 1 \\
&<1 \\
&<1\end{aligned}$ & $\begin{aligned} & *<16 \\
& *<16 \\
&<16 \\
&<16 \\
&<16 \\
&<16 \\
&<16 \\
&<16 \\
&<16 \\
&<16\end{aligned}$ & $\begin{aligned} &<16 \\
& *<16 \\
&<16 \\
&<16 \\
&<16 \\
&<16 \\
&<16 \\
&<16 \\
&<16 \\
&<16\end{aligned}$ & $\begin{array}{l}<16 \\
<16 \\
<16 \\
<16 \\
<16 \\
<16 \\
<16 \\
<16 \\
<16\end{array}$ \\
\hline $\begin{array}{l}11 \\
13 \\
14 \\
15 \\
16 \\
17 \\
18 \\
20 \\
22 \\
23\end{array}$ & $\begin{array}{l}\bar{z} \\
z \\
z \\
z \\
= \\
+ \\
+\end{array}$ & $\begin{array}{l}\bar{z} \\
\bar{z} \\
\bar{z} \\
z \\
\bar{z} \\
\bar{y}\end{array}$ & $\begin{array}{l}\bar{z} \\
= \\
\bar{z} \\
z \\
\bar{z} \\
\bar{y}\end{array}$ & $\begin{array}{l}\bar{z} \\
= \\
z \\
z \\
z \\
=\end{array}$ & $\begin{array}{rl} & 1 \\
& 1 \\
< & 1 \\
< & 1 \\
< & 1 \\
< & 1 \\
1 & 2 \\
& 3\end{array}$ & $\begin{array}{l}<16 \\
<16 \\
<16 \\
<16 \\
<16 \\
<16 \\
<16 \\
<16 \\
* 128\end{array}$ & $\begin{array}{l}<16 \\
<16 \\
<16 \\
<16 \\
<16 \\
<16 \\
<16 \\
<64 \\
* 512\end{array}$ & $\begin{array}{l}<16 \\
<16 \\
<16 \\
<16 \\
<16 \\
<16 \\
<16 \\
<16 \\
* 64 \\
* 64\end{array}$ \\
\hline $\begin{array}{l}26 \\
28 \\
29 \\
31 \\
33 \\
34 \\
35 \\
39 \\
41 \\
43\end{array}$ & $\begin{array}{l}- \\
\pm \\
+ \\
+ \\
+ \\
+ \\
+ \\
+\end{array}$ & $\begin{array}{l}- \\
\pm \\
+ \\
+ \\
\pm \\
+ \\
+ \\
+\end{array}$ & $\begin{array}{l}- \\
\pm \\
+ \\
+ \\
+ \\
\pm \\
- \\
+\end{array}$ & $\begin{array}{l}- \\
\overline{-} \\
+ \\
\pm \\
\overline{-} \\
\overline{-} \\
+\end{array}$ & $\begin{array}{l}2 \\
3 \\
2 \\
3 \\
3 \\
3 \\
3 \\
2 \\
4 \\
4\end{array}$ & $\begin{array}{r}<16 \\
128 \\
<16 \\
* 2048 \\
>2048 \\
<16 \\
128 \\
<16 \\
128 \\
2048\end{array}$ & $\begin{array}{r}<16 \\
64 \\
<16 \\
* 2048 \\
1024 \\
<16 \\
256 \\
<16 \\
1024 \\
256\end{array}$ & $\begin{array}{r}<16 \\
128 \\
<16 \\
512 \\
128 \\
<16 \\
<16 \\
<16 \\
256 \\
128\end{array}$ \\
\hline $\begin{array}{l}44 \\
47 \\
48 \\
49 \\
51 \\
52 \\
55 \\
56 \\
57 \\
58\end{array}$ & $\begin{array}{l}- \\
+ \\
+ \\
+ \\
+ \\
+ \\
+ \\
+ \\
+ \\
+\end{array}$ & $\begin{array}{l}- \\
+ \\
+ \\
+ \\
+ \\
+ \\
+ \\
+ \\
+ \\
+\end{array}$ & $\begin{array}{l}- \\
+ \\
+ \\
+ \\
+ \\
+ \\
+ \\
+ \\
+ \\
+\end{array}$ & $\begin{array}{l}- \\
+ \\
+ \\
+ \\
+ \\
+ \\
+ \\
+ \\
+ \\
+\end{array}$ & $\begin{array}{l}5 \\
4 \\
4 \\
6 \\
4 \\
6 \\
4 \\
6 \\
6 \\
5\end{array}$ & $\begin{array}{r}<16 \\
* 1024 \\
1024 \\
512 \\
>2048 \\
512 \\
512 \\
32 \\
32 \\
512\end{array}$ & $\begin{array}{r}<16 \\
* 2048 \\
512 \\
256 \\
2048 \\
1024 \\
512 \\
16 \# \\
<16 \# \\
64\end{array}$ & $\begin{array}{r}<16 \\
512 \\
128 \\
32 \\
128 \\
256 \\
1024 \\
16 \\
<16 \\
128\end{array}$ \\
\hline $\begin{array}{l}59 \\
61 \\
62 \\
64 \\
69 \\
70 \\
71 \\
72 \\
73 \\
74\end{array}$ & $\begin{array}{l}+ \\
+ \\
+ \\
+ \\
+ \\
+ \\
+ \\
+ \\
+ \\
+\end{array}$ & $\begin{array}{l}+ \\
+ \\
+ \\
+ \\
+ \\
+ \\
+ \\
+ \\
+ \\
+\end{array}$ & $\begin{array}{l}+ \\
+ \\
+ \\
+ \\
+ \\
+ \\
+ \\
+ \\
+ \\
+\end{array}$ & $\begin{array}{l}- \\
+ \\
+ \\
+ \\
+ \\
+ \\
+ \\
+ \\
+\end{array}$ & $\begin{array}{l}4 \\
7 \\
8 \\
7 \\
7 \\
9 \\
7 \\
7 \\
9 \\
9\end{array}$ & $\begin{array}{r}64 \\
* 1024 \\
* \quad 256 \\
256 \\
256 \\
64 \\
32 \\
16 \\
1024 \\
128\end{array}$ & $\begin{array}{c}128 \\
* 512 \\
* 128 \\
1024 \\
64 \\
16 \# \\
16 \# \\
64 \\
128 \\
128\end{array}$ & $\begin{array}{r}32 \\
32 \\
64 \\
128 \\
128 \\
16 \\
<16 \\
<16 \\
64 \\
64\end{array}$ \\
\hline $\begin{array}{l}75 \\
76 \\
77 \\
81 \\
84 \\
85 \\
88 \\
89 \\
91 \\
92\end{array}$ & $\begin{array}{l}+ \\
+ \\
+ \\
- \\
- \\
= \\
+ \\
+\end{array}$ & $\begin{array}{l}+ \\
+ \\
\pm \\
\pm \\
= \\
= \\
+ \\
+ \\
+\end{array}$ & $\begin{array}{l}+ \\
+ \\
\pm \\
\pm \\
- \\
- \\
= \\
+ \\
+\end{array}$ & $\begin{array}{l}+ \\
+ \\
\pm \\
\pm \\
= \\
= \\
\pm \\
+ \\
+\end{array}$ & $\begin{array}{r}9 \\
8 \\
9 \\
<1 \\
11 \\
<1 \\
3 \\
2 \\
6 \\
4\end{array}$ & $\begin{array}{r}256 \\
256 \\
\quad * 64 \\
<16 \\
<16 \\
<16 \\
<16 \\
<16 \\
1024 \\
512\end{array}$ & $\begin{array}{r}64 \\
512 \\
* 32 \\
<16 \\
<16 \\
<16 \\
<16 \\
<16 \\
1024 \\
1024\end{array}$ & $\begin{array}{r}32 \\
64 \\
* 16 \\
<16 \\
<16 \\
<16 \\
<16 \\
<16 \\
512 \\
256\end{array}$ \\
\hline $\begin{array}{r}95 \\
96 \\
98 \\
99 \\
100\end{array}$ & $\begin{array}{l}+ \\
+ \\
+ \\
+ \\
-\end{array}$ & $\begin{array}{l}+ \\
+ \\
+ \\
+ \\
-\end{array}$ & $\begin{array}{l}+ \\
+ \\
+ \\
-\end{array}$ & $\begin{array}{l}+ \\
+ \\
+ \\
+\end{array}$ & $\begin{array}{l}9 \\
9 \\
8 \\
8 \\
1\end{array}$ & $\begin{array}{r}128 \\
1024 \\
64 \\
* 32 \\
<\quad 16\end{array}$ & $\begin{array}{r}32 \\
256 \\
32 \\
* 16 \\
<\quad 16\end{array}$ & $\begin{array}{r}128 \\
512 \\
256 \\
* 16 \\
32\end{array}$ \\
\hline
\end{tabular}

* PA titer after absorption with unsensitized particles.

\# PA titer by the improved reagent was $1: 32$.

$I-1, I-2$ and $I-3$ indicate the first, second and third primary vaccination, respectively, and II indicates a booster vaccination. 
were consistent with those of the pertussis ELISA test, indicating that the pertussis toxin antibody was not acquired or below the detectable level; it is notable that their antitoxin titers against diphtheria and tetanus were low in parallel. No. 100 serum showed a low level of antibody to pertussis toxin but none of diphtheria or tetanus antitoxins.

\section{DISCUSSION}

This study had two main purposes: one was to examine the sensitivity and specificity of the newly developed PA test in comparison with the conventional methods and the other its acceptance and usefulness for practical use in developed and developing countries.

For the conventional method for tetanus antitoxin assay, we used PHA, which had not been accepted as an alternative of the legal assay method, in vivo neutralization in mice, although the correlation between PHA and mice neutralization has been established (7). Therefore, the final evaluation of the tetanus PA test should be made by the neutralization test in mice. In spite of such a drawback, the tetanus PA test was well comparable in the sensitivity and specificity with PHA assay.

The lower sensitivity of the diphtheria PA test with the first lot of the reagents was improved by coating the gelatin particles with the antigen of an increased concentration.

For the anti-pertussis toxin titer, $10 \mathrm{EU} / \mathrm{ml}$ was set as a cut-off value for the positive antibody level in the ELISA test (10). In our results, all samples with $>10 \mathrm{EU}$ had PA titers $\geqq 1: 64$, and even two with lower titers than $10 \mathrm{EU} / \mathrm{ml}(1.25$ and 5) were 1:64 in PA. Thus, for confirmation of the recent infection or diagnosis purpose of the onset of the diseases, the PA test is sensitive enough. When sera with titers lower than $10 \mathrm{EU} / \mathrm{ml}$ were considered, however, some showed PA titers inconsistent with the ELISA titers. Therefore, further comparative studies are needed to use the PA test to detect antibody of lower levels; for example, to detect transplacentally transmitted maternal antibodies in infants or to assess the response to a primary vaccination.

It is well known that no tetanus antitoxin may be acquired naturally, and detection of the antitoxin should be considered to have been acquired by a tetanus toxoid vaccination. Our comparative studies among DPT antibodies by the PA 
test confirmed that the antitoxin to tetanus is a reliable indicator of tetanus or DPT vaccination. The results are most useful for implementation of EPI when the vaccination rate is unknown or needs to be confirmed. For this purpose, the same procedures for serological assay for antibodies against diphtheria, pertussis and tetanus toxins by the PA test will be of great benefit at the practical sites.

\section{REFERENCES}

1. Ikeda, M., Fujino, R., Matsui, T., Yoshida, T., Komada, H. and Imai, J. (1984): A new agglutination test for serum antibodies to adult T-cell leukemia virus. Gann, 75, 845-848.

2. Fujino, R., Kawato, K., Ikeda, M., Miyakoshi, H., Mizukoshi, M. and Imai, J. (1991): Improvement of gelatin particle agglutination test for detection of anti-HTLV-I antibody. Jpn. J. Cancer Res., 82, 367-370.

3. Nakamura, M., Fujino, R. and Ikeda, M. (1993): Preparation of gelatin particles for use in passive agglutination immunoassay. Kobunshi Ronbunshu, 50, 259-261 (in Japanese).

4. Sato, Y. and Sato, H. (1988): Further characterization of Japanese acellular pertussis vaccine prepared in 1988 by 6 Japanese manufacturers. Tokai J. Exp. Clin. Med., 13, Suppl., 79-88.

5. Ministry of Health and Welfare and National Institute of Health (1992): Pertussis (supplement) p.127-137. In Annual Report of National Epidemiological Surveillance of Vaccine Preventable Diseases, 1991 (in Japanese).

6. Furuya, Y., Shiozawa, K., Kubota, T., Akahane, S. and Matsuya, T. (1992): An ELISA method using polystyrene balls for the assay of serum antibodies against Bordetella pertussis. Bull. Shizuoka Prefec. Inst. Publ. Hlth. Environ. Sci., 35, 75-80 (in Japanese).

7. Kameyama, S. and Kondo, S. (1975): Titration of tetanus antitoxin by passive hemagglutination. I. Titration of a guinea-pig antitoxins at various periods of immunization. Jpn. J. Med. Sci. Biol., 28, 127-138.

8. Miyamura, K., Nishio, S., Ito, A., Murata, R. and Kono, R. (1974): Micro cell culture method for determination of diphtheria toxin and antitoxin titers using VERO cells. J. Biol. Stand., 2, 189-201.

9. Sato, Y., Sato, H., Kodama, H., Uchimura, M., Miwa, N., Kobayashi, T., Yamamoto, E., Fujita, I. and Kumamoto, T. (1991): An improved ELISA system for the measurement of IgG antibodies against pertussis toxin (PT) and filamentous hemagglutinin (FHA) in human sera. Develop. Biol. Stand., 73, 167-174. 
10. Kuno-Sakai, H., Kimura, M., Ohta, K., Oh, Y., Kim, R., Kobayashi, T., Yamamoto, E. and Fujita, I. (1992): A simple and sensitive ELISA of antibodies to pertussis antigens. Vaccine, 10, 350-352.

11. Kimura, M., Kuno-Sakai, H., Sato, Y., Kamiya, H., Nii, R., Isomura, S., Horiuchi, K., Kato, T., Deguchi, M., Saikusa, H., Mortimer, Jr., E. A. and Cherry, J. D. (1991): A comparative trial of the reactogenicity and immunogenicity of Takeda acellular pertussis vaccine combined with tetanus and diphtheria toxoids. Am. J. Dis. Child., 145, 734-741.

12. Sato, H. and Takahashi, M. (1994): Tetanus toxoid. p.81-90. In Gakuyukai, National Institute of Health (ed.), Vaccine Handbook, Maruzen, Tokyo (in Japanese). 